\title{
A Comparative Study between the Fama and French Three-Factor Model and the Fama and French Five-Factor Model: Evidence from the Egyptian Stock Market
}

\author{
Nada S. Ragab ${ }^{1}$, Rabab K. Abdou ${ }^{1} \&$ Ahmed M. Sakr ${ }^{1}$ \\ ${ }^{1}$ College of Management and Technology, Arab Academy for Science and Technology and Maritime Transport, \\ Egypt \\ Correspondence: Rabab K. Abdou, College of Management and Technology, Arab Academy for Science and \\ Technology and Maritime Transport, Egypt. Tel: 002-010-0658-1552. E-mail: Rababkhamis@ aast.edu
}

Received: November 17, 2019

Accepted: December 20, 2019 Online Published: December 21, 2019

doi:10.5539/ijef.v12n1p52

URL: https://doi.org/10.5539/ijef.v12n1p52

\begin{abstract}
The focus of this paper is to test whether the Fama and French three-factor and five factor models can capture the variations of returns in the Egyptian stock market as one of the growing emerging markets over the time-period July 2005 to June 2016. To achieve this aim, following Fama and French (2015), the authors construct the Fama and French factors and three sets of test portfolios which are: 10 portfolios double-sorted on size and the BE/ME ratio, 10 portfolios double-sorted on size and operating profitability, and 10 portfolios double-sorted on size and investment for the Egyptian stock market. Using time-series regressions and the GRS test, the results show that although both models cannot be rejected as valid asset pricing models when applied to portfolios double-sorted on size and the BE/ME ratio, they still leave substantial variations in returns unexplained given their low adjusted $\mathrm{R}^{2}$ values. Similarly, when the two models are applied to portfolios double-sorted on size and investment, the results of the GRS test show that both models cannot be rejected. However, when the two models are applied to portfolios double-sorted on size and operating profitability, the results of the GRS test show that both models are strongly rejected which imply that both models leave substantial variations in returns related to size and profitability unexplained. Specifically, the biggest challenge to the two models is the big portfolio with weak profitability which generate a significantly negative intercept implying that the models overestimate its return.
\end{abstract}

Keywords: anomalies, Egyptian stock market, Fama and French Three-Factor Model, Fama and French Five-Factor Model

\section{Introduction}

The study of how financial assets are priced which is referred to as "Asset Pricing" has long been one of the most controversial areas in finance. However, it is still highly debatable how investors measure risk and determine the required risk premium despite the wide array of asset pricing models that has emerged since the development of the Capital Asset Pricing Model (henceforth, the CAPM) by Sharpe (1964), Lintner (1965) and Mossin (1966) which marks the birth of asset pricing models.

The increased interest of researchers to develop and test asset pricing models emerges from the fact that identifying and interpreting the determinants of stock returns have more than a few practical uses. Financial advisors and investors use their understanding of the determinants of stock returns and their associated risks to select assets and construct portfolios that maximize their returns relative to any constraint. Furthermore, asset pricing models are used in capital budgeting decisions to choose the appropriate discount rates to be used in evaluating different investments (Gregory et al., 2013).

However, despite the importance of developing and testing asset pricing models in different contexts, it is quite noticeable that most of the empirical studies and researches on asset pricing models and determinants of stock returns have been conducted in developed markets such as the U.S. market and some European markets. Nonetheless, since developed markets have extremely different characteristics than that of emerging markets it is not possible to generalize their findings to emerging markets (Dash \& Mahakud, 2014). Specifically, emerging markets are normally characterized by thin trading, illiquidity, small number of listed firms, small number of 
investment research institutions and less corporate governance enforcement (Elsayed, 2018). Therefore, standard asset pricing models that are normally developed and tested in developed markets may fail to account for these special circumstances prevalent in emerging markets. Thus, this makes identifying an appropriate asset pricing model for emerging markets one of the challenging tasks in the finance literature.

In this regard, one of the growing emerging markets that is currently viewed by investors as an attractive emerging market is the Egyptian market. After the Egyptian revolutions in 2011 and 2013, the Egyptian government has set an ambitious plan to motivate foreign direct investments (hereafter, FDIs) as shown in Table 1 that reflects the increase in the FDIs in Egypt after the Egyptian revolutions. This upsurge in both domestic investments and foreign investments intensifies the need to determine an appropriate asset pricing models for both foreign and local investors to use in evaluating their investments. However, there is a very limited number of studies that test asset pricing models in emerging markets and the Egyptian stock market is no exception. Thus, to fill in this gap, the aim of this paper is to test whether the Fama and French three-factor and five-factor models can explain stock returns in the Egyptian stock market given their satisfactorily performance in developed markets.

Table 1. FDIs in Egypt from 2005 to 2016

\begin{tabular}{lcccccccccccc}
\hline Year & 2005 & 2006 & 2007 & 2008 & 2009 & 2010 & 2011 & 2012 & 2013 & 2014 & 2015 & 2016 \\
\hline Net FDI (US\$ mn) & 3902 & 6111 & 11053 & 13237 & 8113 & 6758 & 2189 & 3982 & 3753 & 4178 & 6380 & 6933 \\
\hline
\end{tabular}

Source: Central Bank of Egypt.

\subsection{Research Objectives and Importance}

The aim of this study is to analyze whether the Fama and French three-factor and five-factor models can explain stock returns in the Egyptian stock market. This overall aim can be divided into the following objectives

1) Test whether size, value, profitability, and investment patterns exist in the Egyptian stock market.

2) Test whether the Fama and French three-factor model can explain stock returns in the Egyptian stock market using portfolios double-sorted on size and book-to-market ratio, size and profitability and size and investment as the main test portfolios.

3) Test whether the Fama and French five-factor model can explain stock returns in the Egyptian stock market using portfolios double-sorted on size and book-to-market ratio, size and profitability and size and investment as the main test portfolios.

4) Compare between the performances of both models and provide recommendations for practitioners and academics.

\subsubsection{The Academic Perspective}

Given the lack of research studies that test asset pricing models in emerging markets, the academic value of this paper emerges from providing an out-of-sample tests of the Fama and French three-factor and five-factor models by testing whether these models can explain stock returns in the Egyptian stock market which is one of the growing emerging markets. Drew and Veeraraghavan (2002) argue that emerging markets provide a very good approach to provide an out-of-sample test because they have significantly different economic, political, structural, and institutional factors compared to their developed counterparts.

Furthermore, since the development of the Fama and French five factor model in 2015, many studies attempt to provide evidence on the existence of profitability and investment patterns in international markets and test whether the model can explain these patterns. Nonetheless, the inconsistencies of the results of these studies about the existence of investment and profitability patterns in international markets highlight the need to test for the existence of these anomalies in emerging markets such as the Egyptian market. In addition, despite the existence of investment and profitability patterns in several markets, few studies focus on analyzing whether standard asset pricing models can explain these patterns (El Abd, 2016). Thus, this paper tests whether the Fama and French three-factor and five-factor models can explain these patterns in the Egyptian contexts.

\subsubsection{The Practical Perspective}

The practical importance of this research emerges from the following aspects. First, the increase in the number of FDIs in Egypt necessitates the availability of asset pricing models that can provide hurdle rates of returns to evaluate these investments (Abdou, 2019). Second, by analyzing whether size, value, profitability and investment anomalies exist in the Egyptian market and whether they can be explained by standard asset pricing 
models, this paper can determine whether these patterns are due to risk or behavioural biases. These results can provide useful insights for investors in setting their investing strategies that try to exploit the return patterns available in the market.

\section{Literature Review}

\subsection{Development of Asset Pricing Models}

Understanding asset prices and their determinants is of crucial importance not only for investors but also for the economy as a whole. Thus, a substantial part of research effort in the finance literature has been devoted to improving our understanding of how investors value risky cash flows (Jagannathan \& Wang, 1996). The first remarkable asset pricing model, in this regard, is the CAPM which provides the foundation for all succeeding asset pricing models.

Motivated by Harry Markowitz's Modern Portfolio theory (1952), William Sharpe (1964), John Lintner (1965) and Jan Mossin (1966) simultaneously and independently developed the CAPM that can exhibit the relationship between the risk of a specific asset or a portfolio of stocks and the expected return in a precise way. In essence, the CAPM states that the expected return of any stock $\left(E\left(R_{i}\right)\right)$ is a function of the risk-free rate $\left(R_{f}\right)$ plus a risk premium calculated as the stock's market beta $\left(\beta_{i}\right)$, that is the covariance of its return with the market return divided by the variance of the market return, multiplied by the premium per unit of beta risk measured as the excess return of a broad market portfolio over the risk-free rate $\left(E\left(R_{M}\right)-R_{f}\right)$ as shown in Equation 1.

$$
E\left(R_{i}\right)=R_{f}+\beta_{i}\left(E\left(R_{M}\right)-R_{f}\right)
$$

where

$$
\beta_{i}=\frac{\operatorname{Cov}\left(R_{i}, R_{M}\right)}{\sigma_{M}^{2}}
$$

Despite the simplicity of the model, it receives a great deal of severe criticisms. Specifically, Black (1972), Merton (1973) and, Ross $(1976,1978)$ criticize the CAPM's assumptions deeming them unrealistic. Additionally, Basu (1977) and Banz (1981) argue that the market beta alone is not sufficient to explain expected returns. They report evidence on the relationship between firm specific variables such as earnings-price ratio (hereafter, E/P), size (market value) and leverage (measured as the book value of debt over market value of equity) and expected returns. In this regard, they find that small stocks, stocks with high earnings-price ratio, and stock with high book-to-market ratio (hereafter, BE/ME) earn higher returns than what is predicted by the CAPM. Contrary to the CAPM, the higher returns of these stocks are not associated with higher levels of systematic risk as measured by the CAPM beta.

\subsection{The Fama and French Three-Factor Model}

As a result of the above challenges facing the CAPM, many researchers attempt to respond to these challenges through using multifactor asset pricing models (Shah et al., 2014). Motivated by the theoretical work of Ross (1976) and Merton (1973), researchers start to add factors beyond the market to describe the cross-section of expected returns by arguing that these factors are either proxies for underlying state variables that represent changes in the investment opportunity set or proxies for "factor-mimicking" portfolios in an Arbitrage Pricing Theory (APT) setting. The most remarkable work in this regard is the series of papers by Fama and French (1992, 1993) who propose that most of the empirical anomalies that challenge the CAPM can be explained by the sensitivity to three main factors which are the market factor as postulated by the CAPM, the size factor obtained by having a long position in a portfolio of small stocks and a short position in a portfolio of big stocks and book-to-market factor obtained by having a long position in a portfolio of stocks that have high book-to-market ratio (value stocks) and a short position in a portfolio of stocks that have low book-to-market ratio (growth stocks). Specifically, Fama and French (1993) show that their model can be summarized as shown in Equation 2:

$$
E\left(R_{i t}\right)-R_{f t}=\beta_{i M}\left[E\left(R_{M, t}\right)-R_{f t}\right]+\beta_{i s} E\left(R_{S M B, t}\right)+\beta_{i h} E\left(R_{H M L, t}\right)
$$

where, $E\left(R_{i t}\right)$ is the expected excess return on stock $i$ for month $t$. $E\left(R_{M, t}\right), E\left(R_{S M B, t}\right)$ and $E\left(R_{H M L, t}\right)$ are the three Fama and French factors that represent the expected risk premium on the aggregate market index (excess returns), the expected return of small stock portfolios minus the return of big stock portfolios, and the expected return of high book-to-market ratio portfolios minus the return of low book to market ratio portfolios, respectively.

Fama and French (1993) test whether their model can capture common variations in stock returns related to size and book-to-market equity in the US market as they are considered as the most prominent anomalies facing the CAPM. To achieve their aim, they run time-series regression using 25 portfolios double-sorted on size and book-to-market ratio as the main test assets. Their results show that the $\mathrm{R}^{2}$ statistics of almost all of the portfolios 
are above $90 \%$ which implies that the model can capture strong common variations in returns as compared to the CAPM. Furthermore, the intercepts of the 25 portfolios are close to zero which implies that the model can capture cross-sectional variations in stock returns.

Despite the empirical success of the model documented in Fama and French (1993), Daniel and Titman (2012) and Lewellen et al. (2010) argue that these results are due to flawed or biased methodology as it is expected that the SMB and HML factors that are formed from the intersection of the size and BE/ME portfolios can explain the returns of portfolios double-sorted on size and book-to-market ratio. Thus, one way to respond to this criticism is to expand the set of test assets by including portfolios sorted in other ways.

However, despite this criticism, Shaker and Elgiziry (2014) test the Fama and French three-factor model in the Egyptian stock market by using six portfolios double-sorted on size and book-to-market ratio as the main test assets. Their results show that the Fama and French model is the best asset pricing model for the Egyptian stock market as it outperforms other models (Note 1) in explaining stock returns. Nonetheless, given the criticism of Daniel and Titman (2012) and Lewellen et al. (2010), the results of Shaker and Elgiziry are inconclusive and cannot be generalized. Thus, the absence of a valid asset pricing model for the Egyptian stock market leaves managers, investors, and academics in a difficult position (Gregory et al., 2013). Therefore, following Lewellen et al. (2010), this research tests the performance of the model on a broader set of portfolios in order to provide more rigorous test of the model.

\subsection{The Fama and French Five-Factor Model}

Despite the empirical success of the Fama and French three-factor, some researchers start to document additional patterns in average returns related to profitability and investment after years of its development. Novy-Marx (2013) claims that the Fama and French three factor model is an incomplete model of expected returns as it cannot capture most of the variation in average returns related to profitability and investment. This induces Fama and French (2015) to add profitability and investment as additional risk factors to their three-factor model motivated by the recent empirical evidence about the role of both variables in explaining the cross-sectional variation in average stock returns (Novy-Marx, 2013; Aharoni et al., 2013), The five factor model can be expressed as follows:

$$
E\left(R_{i t}\right)-R_{f t}=\beta_{i M}\left[E\left(R_{M, t}\right)-R_{f t}\right]+\beta_{i s} E\left(R_{S M B, t}\right)+\beta_{i h} E\left(R_{H M L, t}\right)+\beta_{i r} E\left(R_{R M W, t}\right)+\beta_{i c} E\left(R_{C M A, t}\right)
$$

where, $E\left(R_{R M W, t}\right)$ represents the difference between the returns on diversified portfolios of stocks with high (robust) and low (weak) profitability, while $E\left(R_{C M A, t}\right)$ is the difference between the returns on diversified portfolios of stocks with low and high investments which are called conservative and aggressive stocks. Fama and French argue that the inclusion of RMW and CMA can be justified within the context of the dividend discount model which suggests that the market value of a stock can be expressed as the discounted value of expected dividends:

$$
p_{t}=\sum_{\tau=1}^{\infty} \frac{E\left(d_{t+\tau}\right)}{(1+r)^{\tau}}
$$

Where $p_{t}$ is the stock price at time $t, E\left(d_{t+\tau}\right)$ represents the expected dividend per share for the time period $(t+\tau)$ and $r$ is the internal rate of return on expected dividends. By manipulating Equation 4, Fama and French establish the link between expected return, expected profitability, expected investment, and the BE/ME ratio to justify their inclusion in the model. Since changes in the book value are approximately equal to earnings less dividends paid (Aretz et al., 2010), the market value of a stock at time $t$ can be expressed as follows (Miller \& Modigliani, 1961).

$$
\frac{M_{t}}{B_{t}}=\sum_{\tau=1}^{\infty} \frac{E\left(Y_{t+\tau}-d B_{t+\tau}\right)}{(1+r)^{\tau}} / B_{t}
$$

where, $Y_{t+\tau}$ is the total equity earnings for the time period $(t+\tau)$ and $d B_{t+\tau}$ represents the change in the total book equity. From Equation 5 three main implications can be derived. First, if everything is held constant in Equation 5 except the current value of the stocks and the expected return. Then, a higher market value of the stock, or equivalently a lower BE/ME ratio, indicates a lower expected return. Second, if everything is held constant except the expected future earnings and the expected stock returns. Then, higher expected earnings imply higher expected return. Finally, holding everything constant except book equity and expected stock returns, Equation 5 shows that higher expected growth in book equity -investment- indicates lower expected return.

Fama and French (2015) test whether the model can provide better explanation of the cross-sectional variations in stock returns compared to their three-factor model through employing three different approaches to construct the five factors stated in Equation 3. The first approach augments Fama and French three factors with investment and profitability factors that aim to capture the investment and profitability patterns in stock returns. In this approach, the size and value factors, consistent with their original paper in 1993, are constructed using 
independent sorts of stocks in two size groups and three BE/ME groups. The intersections of these sorts result in six value-weighted portfolios. The size factor is the difference between average returns of the three small stock portfolios and the three big stock portfolios, while the value factor is the difference between the average returns of the two high BE/ME portfolios and the two low BE/ME portfolios. Similarly, the profitability and investment factors are constructed in the same way as the value factor except that the second sort is either on operating profitability or investment rather than the BE/ME ratio. Inconsistent with Fama and French (1993), the two additional sorts on investment and profitability, generate two additional size factors which are $S M B_{O P}$ and $S M B_{i n v}$ in addition to the original $S M B_{B M}$. Thus, the final SMB factor used in Equation 3 is the weighted average of the $S M B_{O P}, S M B_{i n v}$, and $S M B_{B M}$.

The second approach is similar to the first approach except that the factors are constructed based on $2 \times 2$ independent sorts on size, BM, operating profitability, and investment. Fama and French justify using this approach by arguing that their choice of the $2 \times 3$ sorts is arbitrarily and thus it is important to test whether the asset pricing tests are sensitive to alternative factor definitions. Finally, the third approach is motivated by their findings in 1995 that the value, operating profitability and investment effects are correlated. Specifically, they find that stocks that have high (low) BE/ME ratios tend to have low (high) profitability and investment. Fama and French (2015) argue that the $2 \times 2$ or the $2 \times 3$ sorts do not account for the relationship between the three variables. Thus, to isolate between the premiums in average returns related to size, BE/ME, operating profitability and investment, the final approach they use employ four sorts to control jointly for the four variables. Specifically, they sort stocks independently into two size groups, two BE/ME groups, two operating profitability groups, and two investment groups, and they use the resulting 16 value-weighted portfolios to construct the factors.

Given these three approaches, this paper uses the second approach to construct the factors due to the following reasons. First, Fama and French (2015) show that the three approaches result in similar description of the average returns of the test portfolios and thus no one approach is preferred over the others. Second, due to data availability and the limited number of firms listed in the Egyptian stock market, the second approach, which uses the $2 \times 2$ sorts, results in factors that are better diversified as it uses all the stocks in the sample. Third, Fama and French (2015) argue that although the $2 \times 2 \times 2 \times 2$ sorts better isolate the premiums in average returns related to the value, profitability, and investment effects through using joint controls, multivariate regressions that are used in estimating factor exposures, which are the main focus of asset pricing models, can isolate the exposures to value, profitability and investment patterns as effectively as the factors constructed using the $2 \times 2 \times 2 \times 2$.

Using these different approaches to construct their five factors, Fama and French (2015) find that their five-factor model can provide better explanations of average returns than their three-factor model as it produces lower Gibbons, Ross, and Shanken (GRS) statistics. Furthermore, their results show that the HML factor is redundant for describing average returns in the US for the time period 1963-2013 as it effect is captured by the four other variables included in the model especially the factors related to profitability and investment. However, Fama and French clarify that the redundancy of the HML factor may be sample-specific. Thus, to provide out-of-sample test for the model and determine whether the HML is redundant in other markets and time periods, Fama and French (2017) test whether their five-factor model can explain the cross-sectional variation in stock returns in international markets, specifically, they focus on four regions which are Japan, North America, Europe, and Asia Pacific. Inconsistent with their results in 2015, Fama and French (2017) find that the HML factor is important in describing average returns in the four regions they tested which supports their argument that the redundancy of the HML factor is sample specific and cannot be generalized.

Overall, although the results of Fama and French $(2015,2017)$ show that the Fama and French five-factor model outperforms their three-factor model, the model has two main shortcomings. First, it does not provide a complete description of average returns. Second, the model is an empirical model with poor theoretical underpinnings. Thus, they highlight that the main way to test such empirical models is to test them in different market and time periods to analyze their robustness. In this regard, El Abd (2016) tests the Fama and French five-factor model in the Egyptian stock market over the sample period June 2005 to July 2016. Her results show that relative to the CAPM, the Fama and French three-factor model and the Carhart four-factor model, the Fama and French five-factor model provides the best explanation of the stock returns in the Egyptian stock market. Nonetheless, similar to Fama and French $(2015,2017)$, the model does not provide a complete description of stock returns in the Egyptian stock market.

Although El Abd compares between the Fama and French three-factor and five-factor models in the Egyptian stock market, this paper aims to extend their results to provide more reliable tests on the performance of the model. Specifically, despite the reasons mentioned above on the superiority of the $2 \times 2$ sorts relative to the $2 \times 3$ 
and the $2 \times 2 \times 2 \times 2$ sorts to construct the Fama and French five factors, El Abd uses the $2 \times 3$ sorts and she recommends that future tests of the model should use the $2 \times 2$ sorts instead. Thus, this paper tests whether using different sorting method can affect the results of the model or not.

\section{Research Methodology}

Lozano (2009) argues that the two most commonly used approaches in testing asset pricing models are time-series and cross-sectional regressions. Following Fama and French $(2015,2017)$, this paper uses time-series regression as the main test methodology.

In time-series regression, the main parameters of interest are the intercept, the slopes of the risk factors and the risk premia. In order to estimate these parameters, the excess returns of the test portfolios are regressed on the risk factors under consideration as follows:

$$
R_{i t}-R_{f t}=\alpha_{i}+\sum_{k=1}^{K} \beta_{i k}{ }^{\prime} f_{k t}+\varepsilon_{i t}, \quad t=1,2, \ldots, T, \quad i=1,2, \ldots, N
$$

where $\alpha_{i}$ represent the intercepts, $\beta_{i k}$ represent the factor loadings, and $f_{k t}$ represent the risk factors which include Fama and French three factors and five factors. The above time-series regression is run for each asset $i$ over the time period $t$, to get estimates of the intercepts and the factor loadings. However, to get estimates of the risk premia of each factor, Cochrane (2001) suggests using the sample mean of each risk factor. Specifically, the estimate of the risk premia of the market factor is obtained as the average return of the market portfolio in excess of the risk-free rate over the sample period as follows:

$$
E\left(\hat{\lambda}_{M}\right)=\overline{R_{M}-R_{f}}
$$

Using the estimated parameters from Equation 6, the main test of the validity of the model is the Gibbons, Ross, and Shanken (GRS) (1989) test that determines whether all the $N$ intercepts from Equation 6 are jointly equal to zero. Specifically, the GRS test is estimated as follows:

$$
\frac{T-N-K}{N}\left(1+E_{t}(f)^{\prime} \hat{\Omega}^{-1} E_{t}(f)\right)^{-1} \hat{\alpha}^{\prime} \hat{\Sigma}^{-1} \hat{\alpha} \sim F_{N, T-N-K}
$$

where $T$ is the number of observations, $N$ is the number of portfolios, $K$ is the number of factors, and $\widehat{\Omega}$ is the variance-covariance matrix of the factors. The GRS test rejects the asset pricing model if the statistic is greater than the critical value.

\subsection{Data Collection}

The data for this paper includes monthly returns, size, book equity, the book-to-market ratio, total assets, operating profit, and operating profitability ratio for a sample of 134 stocks listed in the Egyptian stock market. The sample spans the period July 2005 to June 2016. All of the data employed in this paper are collected from the Egypt for Information Dissemination (EGID) Company and DataStream. The basic variables used in this

\begin{tabular}{|c|c|}
\hline Variables & Description \\
\hline Size & $\begin{array}{l}\text { The market equity of the stock calculated as the adjusted closing price on the last trading day of the month } \\
\text { multiplied by the number of shares outstanding. }\end{array}$ \\
\hline Book Equity (BE) & The book value of common equity. \\
\hline $\begin{array}{l}\text { Book-to-Market } \\
\text { Ratio }\end{array}$ & $\begin{array}{l}\text { The firm's book value of equity to the market value of equity. The book value of equity for July of year } t \text { to June } \\
\text { of year } t+1 \text { is calculated using accounting data at the end of year } t-1 \text {. }\end{array}$ \\
\hline Operating Profit & The operating profitability of the firm calculated as EBIT minus interest expense. \\
\hline $\begin{array}{l}\text { Operating } \\
\text { Profitability ratio }\end{array}$ & $\begin{array}{l}\text { The firm's operating profitability divided by the book value of equity. The operating profitability and book value of } \\
\text { equity for July of year } t \text { to June of year } t+1 \text { is calculated using accounting data at the end of year } t-1 \text {. }\end{array}$ \\
\hline Investment & $\begin{array}{l}\text { The growth in total assets of the firm. The investment ratio for July of year } t \text { to June of year } t+1 \text { is calculated as } \\
\text { the percentage change in the total assets of the firm from fiscal year end year } t-1 \text { to fiscal year end year } t \text {. }\end{array}$ \\
\hline
\end{tabular}
paper along with their descriptions are shown in Table 2.

Table 2. Variables description

\subsection{Construction of the Fama and French (FF) Factors}

The aim of this section is to summarize the construction of the Fama and French factors given the unavailability of these factors for the Egyptian stock market.

Following Fama and French (1993), the first factor to construct is the market factor that is defined as the excess return on the market portfolio. It is formulated as the difference between the value-weighted return of all of the stocks used in the sample and the three-month Treasury bill rate that is used as a proxy for the risk-free rate of 
return.

The $\mathrm{SMB}_{\mathrm{BM}}$ and HML factors are constructed from portfolios formed based on $2 \times 2$ sorts on size and the $\mathrm{BE} / \mathrm{ME}$ ratio. Although the choice of the $2 \times 2$ sort is arbitrarily, it is justified by the argument proposed on Section 2.3. For a stock to be included in the factor construction process, it must have a stock price for December of year $t-1$ and June of year $t$, and book equity for year $t-1$. To construct the SMB and HML factors, two main steps are required. The first step aims to sort stocks ascendingly according to their market capitalization at the end of June of year $t$. Then, the median of the market capitalization is calculated. Finally, stocks whose market capitalizations are below the median are classified as small stocks (S), whereas stocks whose market capitalizations are above the median are classified as big stocks (B).

The second step to construct the $\mathrm{SMB}_{\mathrm{BM}}$ and the HML factors requires sorting stocks in an ascending order with respect to their BE/ME ratio. The BE/ME ratio is calculated as the ratio of the book value of stockholders' equity for the fiscal year ending in calendar year $t-1$, to the market equity at the end of December $t-1$. Regardless of the fiscal year end of the firms, the market capitalization at the end of December is used to calculate the firm $\mathrm{BE} / \mathrm{ME}$ ratios to neutralize the impact of market conditions on the ratio. Firms that have negative BE/ME ratios are excluded from the sample when determining the breakpoint of the BE/ME ratio. Similar to the market capitalization, the breakpoint of the BE/ME ratio is the median. Stocks whose BE/ME ratios are below the median are classified as stocks with low BE/ME ratio $(\mathrm{L})$ or growth stocks, while stocks whose BE/ME ratios are above the median are classified as stocks with high $\mathrm{BE} / \mathrm{ME}$ ratio $(\mathrm{H})$ or value stocks.

From the intersection of the two size portfolios and the two BE/ME portfolios, four portfolios are constructed which are: SH, SL, BH, BL. In this regard, the $\mathrm{SH}$ portfolio includes stocks that are in the small market capitalization portfolio and that are also in the high BE/ME portfolio. Then, the monthly value-weighted return for each of these portfolios from July of year $t$ to June of year $t+1$ is calculated. Returns are calculated starting from July to ensure that the book equity for year $t-1$ has been announced to the public.

Finally, the $\mathrm{SMB}_{\mathrm{BM}}$ factor is constructed as the difference between the simple average returns of the two portfolios of small stocks (SH and SL) and the simple average of the returns on the two portfolios of big stocks (BH and BL) as shown in Equation 9:

$$
S M B_{B M}=\frac{(S H+S L)}{2}-\frac{(B H+B L)}{2}
$$

Similarly, the HML factor is constructed monthly as the difference between the simple average returns on the two portfolios of stocks with high $\mathrm{BE} / \mathrm{ME}$ ratios $(\mathrm{SH}$ and $\mathrm{BH})$ and the simple average returns on the two portfolios of stocks with low BE/ME ratios (SL and BL) as shown in Equation 10:

$$
H M L=\frac{(S H+B H)}{2}-\frac{(S L+B L)}{2}
$$

The profitability and investment factors are constructed as the HML factor except that the second sort is either on operating profitability or investment. In this regard, the operating profitability variable that is used in constructing the profitability factor (RMW) is estimated as Earnings Before Taxes "EBT" (Sales minus COGS minus Selling, General and Administrative expenses minus Interest) divided by the BE. Both operating profitability and $\mathrm{BE}$ are calculated using data from the fiscal year ending in calendar year $t-1$ to construct portfolios in June of year $t$. In sorting stocks based on operating profitability, two portfolios are formulated. The first portfolio is the one that includes stocks whose operating profitability is below the median and it is called the weak portfolio $(\mathrm{W})$, while the second one includes stocks whose operating profitability is above the median and it is called the robust portfolio $(\mathrm{R})$.

From the intersection of the two size portfolios and the two operating profitability portfolio, four portfolios are constructed which are: SW, SR, BW, BR. For each one of these portfolios, monthly value-weighted returns are calculated from July of year $t$ to June of year $t+1$. Hence, two additional factors are calculated: $S M B_{O P}$ and $\mathrm{RMW}$. The $\mathrm{SMB}_{\mathrm{OP}}$ factor is the difference between the simple average returns of the two portfolios of small stocks (SW and SR) and the simple average of the returns on the two portfolios of big stocks (BW and BR) as shown in Equation 11:

$$
S M B_{O P}=\frac{(S W+S R)}{2}-\frac{(B W+B R)}{2}
$$

The RMW factor is the difference between the simple average returns of the two portfolios of stocks with robust operating profitability (SR and BR) and the simple average returns of the two portfolios of stocks with weak operating profitability (SW and BW) as shown in Equation 12:

$$
R M W=\frac{(S R+B R)}{2}-\frac{(S W+B W)}{2}
$$

Finally, the investment ratio that is used to construct the investment factor in June of year $t$ is calculated as the 
percentage change in total assets from fiscal year ending in calendar year $t-2$ to fiscal year ending in calendar year $t-1$. Using this investment ratio, stocks are divided into two portfolios. The first one includes stocks whose investment ratio is below the median and it is called the conservative portfolio, whereas the second one includes stocks whose investment ratio is above the median and it is called the aggressive portfolio.

Then, from the intersection of the two size portfolios and the two investment portfolios, four portfolios are constructed which are: SC, SA, BC and BA. For each one of these portfolios, monthly value-weighted returns are calculated from July of year $t$ to June of year $t+1$. Hence, two additional factors are calculated: $S M B_{\mathrm{INV}}$ and CMA. The $\mathrm{SMB}_{\mathrm{INV}}$ factor is the difference between the simple average returns of the two portfolios of small stocks (SC and SA) and the simple average returns of the two portfolios of big stocks (BC and BA) as shown in Equation 13:

$$
S M B_{I N V}=\frac{(S C+S A)}{2}-\frac{(B C+B A)}{2}
$$

The CMA factor is the difference between the simple average returns of the two portfolios of stocks with conservative asset growth (SC and $\mathrm{BC}$ ) and the simple average returns on the two portfolios of stocks with aggressive asset growth (SA and $\mathrm{BA}$ ) as shown in Equation 14:

$$
C M A=\frac{(S C+B C)}{2}-\frac{(S A+B A)}{2}
$$

The construction of the CMA and the RMW factors leads to the emergence of the two additional size factors which are the $\mathrm{SMB}_{\mathrm{OP}}$ and the $\mathrm{SMB}_{\mathrm{INV}}$. Thus, unlike the Fama and French three-factor model, the SMB factor used in the Fama and French five-factor model is calculated as the average of $\mathrm{SMB}_{\mathrm{BM}}, \mathrm{SMB}_{\mathrm{OP}}$, and $\mathrm{SMB}_{\mathrm{INV}}$ as in Equation 15:

\subsection{Construction of the Left-Hand-Side Portfolios}

$$
S M B=\frac{S M B_{B M}+S M B_{O P}+S M B_{I N V}}{3}
$$

Following Fama and French (2015), the left-hand-side (hereafter, LHS) portfolios are finer sorts of the portfolios used to construct the Fama and French factors. Specifically, the LHS portfolios are divided into three sets. The first set of portfolios is constructed on size-BE/ME, the second set of portfolios is constructed on size-OP/BE, and the third set of portfolios is constructed on size-investment. Independent to the size sort that divides stocks into two size groups (small and big) at the end of June of year $t$, stocks are allocated into one of the five portfolios based on book-to-market ratio, operating profitability and investment to construct five book-to-market portfolios, five profitability portfolios and five asset growth portfolios. The intersections of these independent double sorts lead to three different sets of 10 portfolios which are; size and book-to-market, size and profitability, and size and asset growth. Then, the monthly value-weighted returns for these portfolios are calculated over the subsequent 12 months after the portfolio construction.

\section{Descriptive Statistics of the FF Factors}

The aim of this section is to present the descriptive statistics of the FF factors. The importance of this section emerges from providing some insights about the existence of size, value, investment and profitability anomalies in the Egyptian stock market which can be considered as an out-of-sample test of the existence of these anomalies given the significant differences between the Egyptian stock market and developed markets. Tables 3 shows the descriptive statistics of the FF factors. The mean return of the market factor is $0.68 \%$ per month which is equivalent to $8.16 \%$ per year, however it is statistically insignificant. The insignificance of the market returns can be attributed to the turbulence that Egyptian stock market witnessed during the sample period which is apparent from the high standard deviation of the market factor which is equal to $8.39 \%$ per month. Specifically, the sample period includes remarkable events that have major effects on the Egyptian stock market such as the Global Financial Crisis, the Arab Spring in 2011, and the Egyptian Revolutions in 2011 and 2013.

Unlike the market factor, the mean return of the $\mathrm{SMB}_{\mathrm{BM}}$ factor, that aims to mimic the risk factor in returns related to firm size, is $2.85 \%$ per month which is equivalent to $34.2 \%$ per year and it is statistically and economically significant. Consistent with these results, the SMB factor, that is constructed as the weighted average of the $\mathrm{SMB}_{\mathrm{BM}}, \mathrm{SMB}_{\mathrm{OP}}$, and $\mathrm{SMB}_{\mathrm{INV}}$ as illustrated in Section 3.2, has a positive and significant mean return of $2.81 \%$ per month. These results provide preliminarily evidence about the existence of the size effect in the Egyptian stock market.

Inconsistent with Fama and French (1993), the mean return of the HML factor, which aims to mimic the risk factor in returns related to the book-to-market ratio, is $-1.11 \%$ per month which is equivalent to $-13.32 \%$ year and it is statistically significant. These results reflect that value stocks, that have high BE/ME ratio, underperform growth stocks, that have low BE/ME ratio, in the Egyptian stock market during the sample period. 
These results contradict the previous results in both developed and emerging markets about the existence of the value premium (Fama \& French, 1993; Avramov \& Chordia, 2006). However, the negative value premium may be attributed to the $2 \times 2$ sort employed in this paper. This sorting method may introduce some bias to the results because it does not use the extreme value and growth stocks in calculating the return of the HML factor. Furthermore, according to Lakonishok et al. (1994), if value stocks are fundamentally riskier than growth stocks, then there should be sometimes when value stocks underperform growth stocks particularly when marginal utility of wealth is high during economic recessions. Given the argument of Lakonishok et al., the negative value premium observed in Table 3 may be attributed to the political, economic and financial instability that the Egyptian stock market passed by during the sample period.

The mean return of the CMA factor, which aims to mimic the risk factor in returns related to investment, is $0.88 \%$ per month which is equivalent to $10.56 \%$ per year and it is statistically significant at the $5 \%$ level. These results imply the existence of investment effect in the Egyptian stock market. However, these results contradict the results of El Abd (2016) who argues against the existence of the investment effect in the Egyptian stock market. This contradiction can be attributed mainly to the different sorting methods used in the construction of the factors.

Finally, the mean return of the RMW factor, that is used to mimic the risk factor in returns related to operating profitability, is $0.59 \%$ per month which is equivalent to $7.08 \%$ per year but it is statistically insignificant. These results reflect the absence of the profitability effect in the Egyptian stock market.

Table 3. Descriptive statistics for the Fama and French factors

\begin{tabular}{ccccccc}
\hline Factors & Mean $(\%)$ & Standard Deviation $(\%)$ & Sig. Level (Mean =0) & Skewness & Excess Kurtosis & Jarque-Bera (Sig. Level) \\
\hline Market Factor & 0.68 & 8.39 & 0.35 & -0.17 & 1.58 & $14.31(0.00)$ \\
SMB $_{\text {BM }}$ & 2.85 & 9.63 & 0.00 & 1.26 & 2.16 & $59.70(0.00)$ \\
HML & -1.11 & 3.91 & 0.00 & -1.70 & 7.27 & $349.17(0.00)$ \\
SMB & 2.81 & 9.29 & 0.00 & 1.30 & 1.91 & $56.46(0.00)$ \\
CMA & 0.88 & 4.99 & 0.05 & 1.61 & 5.32 & $209.46(0.00)$ \\
RMW & 0.59 & 5.09 & 0.19 & 1.15 & 4.96 & $162.21(0.00)$ \\
\hline
\end{tabular}

Note. Table 3 shows the descriptive statistics for the monthly returns of the FF factors for the sample period July 2005 to June 2016 . All the factors are constructed by the authors as outlined in Section 3.2.

Table 4 shows the correlation matrix for the FF factors for the sample period. The first observation is that the size factor is positively correlated with the market. Such a positive correlation is expected as small stocks tend to have higher betas compared to big stocks. Similar to Fama and French (2015), the value, investment and profitability factors are negatively correlated to the market factor. However, inconsistent with Fama and French, the SMB factor is positively correlated with the investment factor and weakly correlated with profitability factor. Furthermore, despite the claims of Fama and French that the value, investment and profitability factors are correlated, the HML factor is weakly negatively correlated with both the CMA and RMW factors.

Table 4. The Correlation Matrix between the FF factors

\begin{tabular}{cccccc}
\hline & Market Factor & SMB & HML & CMA & RMW \\
\hline Market Factor & 1 & 0.3008 & -0.2302 & -0.0477 & -0.3432 \\
SMB & 0.3008 & 1 & -0.5518 & 0.4222 & 0.0132 \\
HML & -0.2302 & -0.5518 & 1 & -0.4014 & -0.2525 \\
CMA & -0.0477 & 0.4222 & -0.4014 & 1 & 0.4888 \\
RMW & -0.3432 & 0.0132 & -0.2525 & 0.4888 & 1 \\
\hline
\end{tabular}

Note. Table 4 shows the correlation matrix between the FF factors for the sample period July 2005 to June 2016 . All the factors are constructed by the authors as outlined in Section 3.2.

To sum up, the descriptive statistics of the FF factors highlight the existence of size and investment effects in the Egyptian stock market as the mean returns of both the size and investment factors are positive and significant. Furthermore, the results show that the value and profitability effects are absent in the Egyptian stock market. However, since the $2 \times 2$ sorts used to construct the FF factors in this paper are arbitrarily chosen, the absence of the value and profitability effects may be attributed to the sorting method. Thus, the following section presents the descriptive statistics of the test portfolios that are finer sorts of the portfolios used to construct the FF factors in an attempt to provide further evidence on the existence of the size, value, investment, and profitability effects in the Egyptian stock market. 


\section{Descriptive Statistics of the Test Portfolios}

The aim of this section is to present the descriptive statistics for the test portfolios to understand the return patterns that are to be explained by the Fama and French three-factor and five-factor models. In this regard, there are three sets of portfolios that are studied which are portfolios double-sorted on market capitalization and the $\mathrm{BE} / \mathrm{ME}$ ratio, portfolios double-sorted on market capitalization and operating profitability and portfolios double-sorted on market capitalization and asset growth.

Panel A of Table 5 shows the average monthly excess return of the 10 portfolios double-sorted on size and the BE/ME ratio for the period July 2005 to June 2016. As outlined in Section 4, the results of Panel A support the existence of a significant size premium in the Egyptian stock market. Specifically, within each BE/ME quintile, the average return decreases monotonically with market capitalization. Furthermore, given the results in Section 4 that document the absence of the value premium in the Egyptian stock market, this section shows that despite using the extreme value and growth stocks, value stocks continue to underperform growth stocks within each size group. These results contradict the vast amount of empirical research documenting the existence of value premium in both developed and emerging markets.

Panel B of Table 5 shows the average monthly excess returns of the 10 portfolios double-sorted on size and operating profitability. As for the size effect, the patterns observed in the 10 Size-OP portfolios are like those observed for the Size-BE/ME portfolios. Holding operating profitability constant, average return typically falls as size increases. Panel B also provides evidence on the existence of the profitability effect in the Egyptian stock market. Consistent with Novy-Marx (2013), within each size group, extreme high operating profitability is associated with higher average return than extreme low operating profitability. These results support the existence of the profitability effect in the Egyptian stock market. However, it should be noted that there is no clear pattern concerning the relationship between average returns and operating profitability in the Egyptian stock market, rather the profitability effect is mainly a low average return for the lowest OP quintile and a high average return for the highest OP quintile. This may, in turn, justify the insignificance of the mean return of the RMW factor as depicted in Section 4.

Panel $\mathrm{C}$ of Table 5 shows the average monthly excess returns of the 10 portfolios double-sorted on size and investment. Similar to the results in Panel A and Panel B, holding investment constant, average return typically falls as size increases supporting the existence of size effect in the Egyptian stock market. Panel C also provides evidence on the existence of the investment effect in the Egyptian stock market. In every size group, the average return of the portfolio in the lowest investment quintile is much higher than the average return of the portfolio in the highest investment quintile. This, in turn, supports the existence of the investment effect in the Egyptian stock market as outlined in Section 4.

Table 5. Descriptive statistics of the test portfolios

\begin{tabular}{|c|c|c|c|c|c|}
\hline & Low & 2 & 3 & 4 & High \\
\hline \multicolumn{6}{|c|}{ Panel A: Size-BE/ME portfolios } \\
\hline \multirow{2}{*}{ Small } & 0.055133 & 0.046450 & 0.022618 & 0.006333 & 0.023361 \\
\hline & $(0.2376)$ & $(0.1823)$ & $(0.1507)$ & $(0.1085)$ & $(0.1464)$ \\
\hline \multirow{2}{*}{ Big } & 0.008547 & 0.001568 & 0.002019 & 0.000621 & -0.001414 \\
\hline & $(0.0861)$ & $(0.0856)$ & $(0.0966)$ & $(0.1006)$ & $(0.0998)$ \\
\hline \multicolumn{6}{|c|}{ Panel B: Size-OP portfolios } \\
\hline \multirow{2}{*}{ Small } & 0.037487 & 0.024170 & 0.024847 & 0.019249 & 0.049330 \\
\hline & $(0.1964)$ & $(0.1763)$ & $(0.1406)$ & $(0.1189)$ & $(0.2111)$ \\
\hline \multirow{2}{*}{ Big } & -0.012883 & 0.009826 & 0.002333 & 0.008766 & 0.002522 \\
\hline & $(0.1305)$ & $(0.1339)$ & $(0.1037)$ & $(0.0943)$ & $(0.0811)$ \\
\hline \multicolumn{6}{|c|}{ Panel C: Size-INV portfolios } \\
\hline \multirow{2}{*}{ Small } & 0.063569 & 0.027361 & 0.023763 & 0.024805 & 0.033879 \\
\hline & $(0.2932)$ & $(0.1534)$ & $(0.1663)$ & $(0.1668)$ & $(0.2059)$ \\
\hline \multirow{2}{*}{ Big } & 0.002303 & 0.002015 & 0.000559 & 0.009594 & -0.001157 \\
\hline & $(0.0945)$ & $(0.1148)$ & $(0.0979)$ & $(0.1026)$ & $(0.0955)$ \\
\hline
\end{tabular}

Note. Table 5 presents the average monthly excess returns for value weighted portfolios formed on (i) size and BE/ME ratio; (ii) size and operating profitability; and (iii) size and investment ratio from July 2005 to June 2016. These three sets of test portfolios are constructed as illustrated in Section 3.3.

To sum up this section, it is apparent that the most prevalent anomaly in the Egyptian stock market is the size effect. Holding BE/ME, operating profitability, and asset growth constant, the average return decreases with firm 
size. Furthermore, the results support the existence of investment effect in the Egyptian stock market. However, the relationship between average returns and investment ratio is less consistent that the relation between average returns and size. Overall, the three sets of test portfolios show wide variations in returns as well as anomalous patterns that pose significant challenges for competing asset pricing models to explain. Thus, the aim of the next sections is to test whether the Fama and French three-factor and five-factor models can explain these patterns.

\section{The Fama and French Three-Factor Model Performance Summary}

This section aims to test whether the Fama and French three-factor model can explain the wide variations in the returns of the test portfolios. Table 6 reports the results of the full-sample time-series regressions of the Fama and French three-factor model for the three sets of the test portfolios. When analyzing the results of the time-series regression several points should be highlighted. First, the intercepts of the time-series regressions should be indistinguishable from zero, if the asset pricing model is well-specified. Second, the slopes of the risk factors employed in the time-series regression provide a direct evidence on whether they can capture common variation in stock returns. Thus, panel A reports the coefficients of the time-series regressions of the 10 portfolios double-sorted on size and BE/ME ratio on the Fama and French three risk factors along with the intercepts and their t-statistics.

The results of Panel A show that all the intercepts of the 10 portfolios are indistinguishable from zero. These results imply that the Fama and French three-factor model can well capture the common variations in stock returns related to size and $\mathrm{BE} / \mathrm{ME}$ ratio. However, these results should be interpreted with caution as the returns of these portfolios are highly volatile as is apparent from the results presented in Table 5 that show that the standard deviations of the returns of these portfolios range from $8.56 \%$ to $23.76 \%$. Fama and French (1993) argue that this high volatility may negatively impact the power of asset pricing tests. However, they emphasize that if the risk factors employed in the time-series regression can capture most of the variations in stock returns, then the inferences drawn from analyzing the intercepts can be precise. To check for this, the adjusted $\mathrm{R}^{2}$ statistics from the time-series regressions are reported in Table 6. The results show that there are substantial variations in returns that cannot be captured by the Fama and French three-factor model as most of the adjusted $\mathrm{R}^{2}$ values are below $70 \%$.

The results of Panel A also show that the variations in market betas are too small to explain the wide variations in the returns of the 10 portfolios double-sorted on size and BE/ME ratio. In contrast, the slopes of the SMB factor show substantial variations across portfolios ranging from 0.004 to 1.108 . Within each BE/ME quintile, the slopes of the SMB factor decreases monotonically with firm size. These results support the role of the SMB factor in explaining the common variations in stock returns related to firm size in the Egyptian stock market. Finally, the coefficients of the HML factor also show substantial variations across portfolios ranging from -1.853 to 2.019. The pattern of the coefficients of the HML factor is worth highlighting. On the one hand, consistent with Fama and French $(1993 ; 1996)$, portfolios that include stocks with low BE/M ratio load negatively on the HML factor, while those that include stocks with high BE/EM load positively on the HML factor. On the other hand, within each size group, the slopes of the HML factor increase almost monotonically with the BE/ME ratio. These results imply that the HML factor contribute towards explaining common variations in stock returns related to the $\mathrm{BE} / \mathrm{ME}$ ratio.

To sum up, although the results of Panel A provide some support for the Fama and French three-factor model, the criticisms of Daniel and Titman (2012) and Lewellen et al. (2010) imply that such favorable results might be misleading. Thus, this section also analyzes whether the Fama and French three-factor model can explain the returns of an extended set of test assets that include portfolios double-sorted on size and operating profitability and portfolios double-sorted on size and asset growth.

Panel B of Table 6 reports the results of the 10 portfolios double-sorted on size and operating profitability. The results show that 9 out of the 10 portfolios have insignificant intercepts. Although, these results show that the model can explain the common variations of stock returns in the Egyptian stock market related to size and profitability, they should be investigated with caution due to the high variability of the returns of these portfolios and the low adjusted $\mathrm{R}^{2}$ values that range from $25.81 \%$ to $70.4 \%$ that reflect that the model leaves substantial variation in returns unexplained. Furthermore, consistent with the results of Lin (2017) in the Chinese stock market, the biggest challenge to the model is the big portfolio with weak profitability which has a significant intercept of $-2.4 \%$ which means that the portfolio earns a lower return than that predicted by the model. These results may be attributed to the following. First, although this portfolio should earn the low premium of low profitability stocks, it has positive loadings on all the three FF factors which may justify why its return is overstated by the model. Second, low profitability stocks are characterized mainly by being small stocks that 
have high BE/ME ratio, thus this portfolio may include only small number of stocks and thus it is affected by company-specific risk that may distort the results. Thus, since this portfolio strongly challenges that Fama and French three-factor model, it is of interest to determine whether the Fama and French five-factor model that includes profitability as an additional risk factor can explain the returns of this portfolio.

Table 6. Coefficients of the FF3 model

\begin{tabular}{|c|c|c|c|c|c|c|c|c|c|c|c|}
\hline \multicolumn{12}{|c|}{ Panel A: Size-BE/ME Portfolios } \\
\hline & Low & 2 & 3 & 4 & High & & Low & 2 & 3 & 4 & High \\
\hline \multicolumn{7}{|c|}{ Intercepts } & \multicolumn{5}{|c|}{ t-statistics } \\
\hline Small & -0.004 & -0.001 & -0.007 & -0.007 & 0.009 & Small & $\begin{array}{c}-0.522 \\
(0.60)\end{array}$ & $\begin{array}{l}-0.115 \\
(0.91)\end{array}$ & $\begin{array}{c}-1.111 \\
(0.27)\end{array}$ & $\begin{array}{l}-1.41 \\
(0.16)\end{array}$ & $\begin{array}{c}1.57 \\
(0.12)\end{array}$ \\
\hline Big & -0.0001 & -0.005 & -0.005 & -0.005 & -0.007 & Big & $\begin{array}{r}-0.030 \\
(0.98) \\
\end{array}$ & $\begin{array}{l}-1.15 \\
(0.25) \\
\end{array}$ & $\begin{array}{c}-0.79 \\
(0.43)\end{array}$ & $\begin{array}{c}-0.79 \\
(0.43) \\
\end{array}$ & $\begin{array}{l}-1.12 \\
(0.26) \\
\end{array}$ \\
\hline \multicolumn{7}{|c|}{ Coefficients of the Market Factor } & \multicolumn{5}{|c|}{ Coefficients of the SMB Factor } \\
\hline Small & $\begin{array}{l}1.039 \\
(6.68)\end{array}$ & $\begin{array}{l}0.886 \\
(8.76)\end{array}$ & $\begin{array}{l}0.769 \\
(5.69)\end{array}$ & $\begin{array}{c}0.781 \\
(10.48)\end{array}$ & $\begin{array}{c}1.062 \\
(11.33)\end{array}$ & Small & $\begin{array}{l}1.108 \\
(6.03)\end{array}$ & $\begin{array}{l}1.005 \\
(8.56)\end{array}$ & $\begin{array}{l}0.927 \\
(6.87)\end{array}$ & $\begin{array}{l}0.709 \\
(8.19)\end{array}$ & $\begin{array}{l}1.029 \\
(8.97)\end{array}$ \\
\hline Big & $\begin{array}{c}0.835 \\
(12.77) \\
\end{array}$ & $\begin{array}{c}0.817 \\
(10.54) \\
\end{array}$ & $\begin{array}{r}0.826 \\
(8.15) \\
\end{array}$ & $\begin{array}{l}0.821 \\
(7.48) \\
\end{array}$ & $\begin{array}{l}0.878 \\
(9.72) \\
\end{array}$ & Big & $\begin{array}{l}0.004 \\
(0.07) \\
\end{array}$ & $\begin{array}{l}0.035 \\
(0.52) \\
\end{array}$ & $\begin{array}{l}0.109 \\
(1.08) \\
\end{array}$ & $\begin{array}{l}0.366 \\
(4.93) \\
\end{array}$ & $\begin{array}{l}0.205 \\
(2.25) \\
\end{array}$ \\
\hline \multicolumn{7}{|c|}{ Coefficients of the HML Factor } & \multicolumn{5}{|c|}{ Adjusted R2 (\%) } \\
\hline Small & $\begin{array}{l}-1.853 \\
(-2.77)\end{array}$ & $\begin{array}{l}-1.117 \\
(-3.26)\end{array}$ & $\begin{array}{l}0.216 \\
(0.48)\end{array}$ & $\begin{array}{l}1.123 \\
(5.92)\end{array}$ & $\begin{array}{l}2.019 \\
(7.28)\end{array}$ & Small & 71.74 & 80.85 & 62.69 & 75.16 & 80.57 \\
\hline Big & $\begin{array}{l}-0.258 \\
(-2.28)\end{array}$ & $\begin{array}{l}-0.012 \\
(-0.09)\end{array}$ & $\begin{array}{l}0.189 \\
(0.89) \\
\end{array}$ & $\begin{array}{l}0.969 \\
(6.02)\end{array}$ & $\begin{array}{l}0.594 \\
(2.97) \\
\end{array}$ & Big & 71.43 & 65.59 & 53.21 & 61.36 & 58.71 \\
\hline \multicolumn{12}{|c|}{ Panel B: Size-OP Portfolios } \\
\hline & Low & 2 & 3 & 4 & High & & Low & 2 & 3 & 4 & High \\
\hline \multicolumn{7}{|c|}{ Intercepts } & \multicolumn{5}{|c|}{ t-statistics } \\
\hline Small & 0.004 & -0.003 & 0.008 & 0.007 & -0.005 & Small & $\begin{array}{l}0.502 \\
(0.61)\end{array}$ & $\begin{array}{l}-0.361 \\
(0.72)\end{array}$ & $\begin{array}{l}0.948 \\
(0.34)\end{array}$ & $\begin{array}{l}0.945 \\
(0.34)\end{array}$ & $\begin{array}{r}-0.663 \\
(0.51)\end{array}$ \\
\hline Big & -0.024 & 0.003 & -0.009 & 0.002 & -0.003 & Big & $\begin{array}{c}-3.01 \\
(0.00) \\
\end{array}$ & $\begin{array}{r}0.353 \\
(0.72) \\
\end{array}$ & $\begin{array}{r}-1.364 \\
(0.17) \\
\end{array}$ & $\begin{array}{l}0.296 \\
(0.77) \\
\end{array}$ & $\begin{array}{r}-0.653 \\
(0.51) \\
\end{array}$ \\
\hline \multicolumn{6}{|c|}{ Coefficients of the Market Factor } & \multicolumn{6}{|c|}{ Coefficients of the SMB Factor } \\
\hline Small & $\begin{array}{l}0.920 \\
(5.23)\end{array}$ & $\begin{array}{l}1.134 \\
(8.00)\end{array}$ & $\begin{array}{l}0.854 \\
(6.21)\end{array}$ & $\begin{array}{l}0.435 \\
(3.34)\end{array}$ & $\begin{array}{l}0.764 \\
(5.18)\end{array}$ & Small & $\begin{array}{l}1.162 \\
(5.23)\end{array}$ & $\begin{array}{l}0.967 \\
(5.35)\end{array}$ & $\begin{array}{l}0.568 \\
(3.54)\end{array}$ & $\begin{array}{l}0.524 \\
(3.52)\end{array}$ & $\begin{array}{l}1.114 \\
(5.99)\end{array}$ \\
\hline Big & $\begin{array}{l}1.017 \\
(7.48) \\
\end{array}$ & $\begin{array}{l}1.081 \\
(7.82) \\
\end{array}$ & $\begin{array}{l}0.786 \\
(8.02) \\
\end{array}$ & $\begin{array}{l}0.801 \\
(8.91) \\
\end{array}$ & $\begin{array}{l}0.699 \\
(9.59) \\
\end{array}$ & Big & $\begin{array}{l}0.381 \\
(3.43) \\
\end{array}$ & $\begin{array}{l}0.054 \\
(0.41) \\
\end{array}$ & $\begin{array}{l}0.199 \\
(2.20) \\
\end{array}$ & $\begin{array}{l}0.115 \\
(1.12) \\
\end{array}$ & $\begin{array}{l}0.063 \\
(0.76) \\
\end{array}$ \\
\hline \multicolumn{6}{|c|}{ Coefficients of the HML Factor } & \multicolumn{6}{|c|}{ Adjusted R2 (\%) } \\
\hline Small & $\begin{array}{l}0.562 \\
(0.74)\end{array}$ & $\begin{array}{c}0.714 \\
(1.29)\end{array}$ & $\begin{array}{l}0.482 \\
(1.08)\end{array}$ & $\begin{array}{l}0.519 \\
(1.07)\end{array}$ & $\begin{array}{l}-1.534 \\
(-3.08)\end{array}$ & Small & 51.95 & 62.09 & 44.25 & 25.81 & 71.04 \\
\hline Big & $\begin{array}{l}0.602 \\
(2.36)\end{array}$ & $\begin{array}{l}0.184 \\
(0.70)\end{array}$ & $\begin{array}{l}0.006 \\
(0.02)\end{array}$ & $\begin{array}{l}0.152 \\
(0.65)\end{array}$ & $\begin{array}{l}0.062 \\
(0.29)\end{array}$ & Big & 52.57 & 44.77 & 49.40 & 53.55 & 53.87 \\
\hline \multicolumn{12}{|c|}{ Panel C: Size-INV Portfolios } \\
\hline & Low & 2 & 3 & 4 & High & & Low & 2 & 3 & 4 & High \\
\hline \multicolumn{7}{|c|}{ Intercepts } & \multicolumn{5}{|c|}{ t-statistics } \\
\hline Small & -0.007 & 0.001 & -0.007 & 0.0103 & 0.009 & Small & $\begin{array}{c}-0.681 \\
(0.49)\end{array}$ & $\begin{array}{l}0.883 \\
(0.93)\end{array}$ & $\begin{array}{c}-0.791 \\
(0.43)\end{array}$ & $\begin{array}{l}1.071 \\
(0.28)\end{array}$ & $\begin{array}{l}0.845 \\
(0.39)\end{array}$ \\
\hline Big & -0.001 & -0.008 & -0.012 & 0.002 & -0.006 & Big & $\begin{array}{c}-0.129 \\
(0.89)\end{array}$ & $\begin{array}{r}-1.079 \\
(0.28)\end{array}$ & $\begin{array}{r}-1.954 \\
(0.05)\end{array}$ & $\begin{array}{l}0.285 \\
(0.78)\end{array}$ & $\begin{array}{r}-1.087 \\
(0.28)\end{array}$ \\
\hline \multicolumn{7}{|c|}{ Coefficients of the Market Factor } & \multicolumn{5}{|c|}{ Coefficients of the SMB Factor } \\
\hline Small & $\begin{array}{l}0.865 \\
(3.74)\end{array}$ & $\begin{array}{c}0.752 \\
(5.04)\end{array}$ & $\begin{array}{l}0.814 \\
(6.52)\end{array}$ & $\begin{array}{l}1.061 \\
(7.64)\end{array}$ & $\begin{array}{l}0.797 \\
(4.44)\end{array}$ & Small & $\begin{array}{c}1.511 \\
(5.97)\end{array}$ & $\begin{array}{l}0.833 \\
(5.39)\end{array}$ & $\begin{array}{l}1.048 \\
(6.02)\end{array}$ & $\begin{array}{l}0.744 \\
(5.06)\end{array}$ & $\begin{array}{l}0.804 \\
(2.29)\end{array}$ \\
\hline Big & $\begin{array}{l}0.807 \\
(8.69) \\
\end{array}$ & $\begin{array}{l}0.877 \\
(7.39) \\
\end{array}$ & $\begin{array}{l}0.706 \\
(5.85)\end{array}$ & $\begin{array}{l}0.891 \\
(8.65)\end{array}$ & $\begin{array}{l}0.842 \\
(8.61)\end{array}$ & Big & $\begin{array}{l}0.075 \\
(0.75)\end{array}$ & $\begin{array}{l}0.341 \\
(2.07)\end{array}$ & $\begin{array}{l}0.204 \\
(2.31)\end{array}$ & $\begin{array}{l}0.019 \\
(0.21)\end{array}$ & $\begin{array}{l}0.023 \\
(0.29) \\
\end{array}$ \\
\hline \multicolumn{7}{|c|}{ Coefficients of the HML Factor } & \multicolumn{5}{|c|}{ Adjusted R2 (\%) } \\
\hline Small & $\begin{array}{l}-1.957 \\
(-2.06) \\
\end{array}$ & $\begin{array}{l}0.203 \\
(0.48)\end{array}$ & $\begin{array}{l}0.444 \\
(1.07)\end{array}$ & $\begin{array}{l}1.257 \\
(3.48)\end{array}$ & $\begin{array}{l}0.274 \\
(0.46)\end{array}$ & Small & 60.75 & 51.85 & 59.31 & 46.77 & 27.35 \\
\hline Big & $\begin{array}{l}0.404 \\
(2.14)\end{array}$ & $\begin{array}{l}0.536 \\
(1.23)\end{array}$ & $\begin{array}{r}-0.180 \\
(-0.76) \\
\end{array}$ & $\begin{array}{l}-0.117 \\
(-0.51) \\
\end{array}$ & $\begin{array}{c}0.098 \\
(0.54)\end{array}$ & Big & 50.08 & 51.13 & 50.39 & 54.43 & 53.40 \\
\hline
\end{tabular}

Note. Table 6 shows the slopes of the Fama and French three risk factors along with their t-statistics in parentheses, the intercepts of the Fama and French three-factor model and their t-statistics with the significance level in parentheses and adjusted $\mathrm{R}^{2}$ values of the full sample time-series regression of the Fama and French three-factor model applied on the 10 portfolios double-sorted on size and the BE/ME ratio, size and OP, and size and INV. The time-series regression is as follows:

$$
R_{i t}^{e}=\alpha_{i}+\beta_{i} R_{M t}^{e}+s_{i} S M B_{t}+h_{i} H M L_{t}+\varepsilon_{i t}
$$


The final remark on the results of these portfolios is related to the coefficients of the three FF factors. Although the coefficients of the market factor and the SMB factors show patterns similar to that observed on the 10 portfolios double-sorted on size and BE/ME ratio, the coefficients of the HML factor turn out to be insignificant for most of the portfolios which indicates that the HML factor does not play a major role in capturing the common variations in returns relate to size and operating profitability.

Panel C of Table 6 reports the results for the 10 portfolios double-sorted on size and investment. Similar to the 10 portfolios double-sorted on size and investment, 9 out of the 10 portfolios have insignificant intercepts. Moreover, the adjusted $\mathrm{R}^{2}$ are also low ranging between $27.35 \%$ and $60.75 \%$. This, in turn, reflects that model cannot fully capture the common variation in returns related to size and investment. These results, along with the results of the 10 portfolios double-sorted on size and profitability, imply that the Fama and French three-factor cannot be considered as an appropriate asset pricing model for the Egyptian stock market.

The coefficients of the market factor and the SMB factor for the 10 portfolios double-sorted on size and investment show similar patterns to that shown in Panel A and Panel B. However, similar to the results of the 10 portfolios double-sorted on size and operating profitability, the coefficients of the HML factor are mostly insignificant. Specifically, only 3 portfolios have significant loadings on the HML factor. This, in turn, indicates that the HML factor does not play a major role in capturing the common variations in returns related to size and investment.

To sum up this section, the results show that the Fama and French three-factor model is strongly challenged by the portfolios double-sorted on size and profitability and portfolios double-sorted on size and investment. This, in turn, opens a fertile area to test whether the Fama and French five-factor model that includes profitability and investment factors can outperform the three-factor model in the Egyptian stock market.

\section{The Fama and French Five-Factor Model Performance Summary}

The purpose of this section is to test whether the Fama and French five-factor model can provide better explanation of returns than the Fama and French three-factor model. Table 7 reports the results of the full-sample time-series regressions of the Fama and French five-factor model for the three sets of the test portfolios. However, since the coefficients of both the market factor and the SMB factors are similar to those reported in Table 6, they are not reported in Table 7 for brevity.

Panel A reports the results for the 10 portfolios double-sorted on size and the BE/ME ratio. The first observation from Panel $\mathrm{A}$ is that all the intercepts are indistinguishable from zero suggesting that the Fama-French five factors are capable of capturing the variations in stock returns. However, for the same reason mentioned in section 6 these results still need cautious interpretation. The adjusted $R^{2}$ statistic results in Table 7 range from $54.97 \%$ to $84.03 \%$ implying that the Fama and French five factor model cannot capture all the variations in stock returns in the Egyptian market. However, the R2 reported in Table 7 are higher than those in Table 6 inferring that the Fama and French five factor model has a higher power in explaining variations in stock returns than the three factor model.

Similar to the results of Table 6, the coefficients of the HML factor remain to show substantial variations across portfolios even after including the RMW and CMA factors. Hence, this indicates that the HML factor plays a role in explaining the cross-sectional variation in stock returns related to the BE/ME in the Egyptian market. However, Panel A shows that almost all of the coefficients of the RMW factor are negative and they are mostly insignificant. These results imply that the profitability factor plays no role in explaining the returns of the 10 portfolios double sorted on size and the BE/ME ratio. Lastly, results in Panel A do not match those of Fama-French (2015), as all portfolios including the ones in the lowest BM quintile load positively on the CMA factor. Additionally, the CMA coefficients of the portfolios in the small size group decrease from the lowest BM quintile to the highest BM quintile which contradicts the argument of Fama and French (2015) that value stocks are more conservative than growth stocks. Overall, the results of Panel A show that the inclusion of the RMW and CMA factors do not contribute much towards explaining the cross-sectional variation in stock returns in the 10 portfolios double-sorted on size and BE/ME ratio. 
Table 7. Coefficients of the FF5F model

\begin{tabular}{|c|c|c|c|c|c|c|c|c|c|c|c|}
\hline \multicolumn{12}{|c|}{ Panel A: Size-BE/ME Portfolios } \\
\hline & Low & 2 & 3 & 4 & High & & Low & 2 & 3 & 4 & High \\
\hline \multicolumn{7}{|c|}{ Intercepts } & \multicolumn{5}{|c|}{ t-statistics } \\
\hline Small & -0.005 & 0.002 & -0.004 & -0.007 & 0.009 & Small & $\begin{array}{l}-0.398 \\
(0.69)\end{array}$ & $\begin{array}{l}-0.238 \\
(0.81)\end{array}$ & $\begin{array}{c}-0.583 \\
(0.56)\end{array}$ & $\begin{array}{c}-1.326 \\
(0.19)\end{array}$ & $\begin{array}{l}1.688 \\
(0.09)\end{array}$ \\
\hline Big & 0.002 & -0.005 & -0.003 & -0.003 & -0.005 & Big & $\begin{array}{l}0.422 \\
(0.67) \\
\end{array}$ & $\begin{array}{c}-1.108 \\
(0.27) \\
\end{array}$ & $\begin{array}{l}-0.563 \\
(0.57) \\
\end{array}$ & $\begin{array}{r}-0.595 \\
(0.55) \\
\end{array}$ & $\begin{array}{l}-0.921 \\
(0.36) \\
\end{array}$ \\
\hline \multicolumn{7}{|c|}{ Coefficients of the HML Factor } & \multicolumn{5}{|c|}{ Coefficients of the RMW Factor } \\
\hline Small & $\begin{array}{l}-1.887 \\
(-5.20)\end{array}$ & $\begin{array}{l}-1.171 \\
(-5.32)\end{array}$ & $\begin{array}{l}-0.388 \\
(-1.85)\end{array}$ & $\begin{array}{l}0.929 \\
(6.31)\end{array}$ & $\begin{array}{c}1.791 \\
(10.91)\end{array}$ & Small & $\begin{array}{l}0.017 \\
(0.06)\end{array}$ & $\begin{array}{l}-0.187 \\
(-1.07)\end{array}$ & $\begin{array}{l}-1.191 \\
(-7.17)\end{array}$ & $\begin{array}{l}-0.384 \\
(-3.29)\end{array}$ & $\begin{array}{l}-0.544 \\
(-4.18)\end{array}$ \\
\hline Big & $\begin{array}{l}-0.428 \\
(-3.66) \\
\end{array}$ & $\begin{array}{l}-0.004 \\
(-0.03) \\
\end{array}$ & $\begin{array}{l}0.041 \\
(0.22) \\
\end{array}$ & $\begin{array}{l}0.753 \\
(4.32) \\
\end{array}$ & $\begin{array}{l}0.402 \\
(2.38) \\
\end{array}$ & Big & $\begin{array}{l}-0.496 \\
(-5.34) \\
\end{array}$ & $\begin{array}{l}-0.072 \\
(-0.64) \\
\end{array}$ & $\begin{array}{l}-0.388 \\
(-2.69) \\
\end{array}$ & $\begin{array}{l}-0.423 \\
(-3.07) \\
\end{array}$ & $\begin{array}{l}-0.582 \\
(-4.35) \\
\end{array}$ \\
\hline \multicolumn{6}{|c|}{ Coefficients of the CMA Factor } & \multicolumn{6}{|c|}{ Adjusted R2 (\%) } \\
\hline Small & $\begin{array}{l}0.776 \\
(2.64)\end{array}$ & $\begin{array}{l}0.589 \\
(3.30)\end{array}$ & $\begin{array}{l}0.159 \\
(0.93)\end{array}$ & $\begin{array}{l}0.272 \\
(2.28)\end{array}$ & $\begin{array}{l}0.451 \\
(3.39)\end{array}$ & Small & 70.42 & 81.50 & 75.36 & 76.61 & 84.03 \\
\hline Big & $\begin{array}{l}0.270 \\
(2.84) \\
\end{array}$ & $\begin{array}{l}0.110 \\
(0.94) \\
\end{array}$ & $\begin{array}{l}0.190 \\
(1.26) \\
\end{array}$ & $\begin{array}{l}0.166 \\
(1.17)\end{array}$ & $\begin{array}{l}0.347 \\
(2.54)\end{array}$ & Big & 76.44 & 65.37 & 54.97 & 61.91 & 63.71 \\
\hline \multicolumn{12}{|c|}{ Panel B: Size-OP Portfolios } \\
\hline & Low & 2 & 3 & 4 & High & & Low & 2 & 3 & 4 & High \\
\hline \multicolumn{7}{|c|}{ Intercepts } & \multicolumn{5}{|c|}{ t-statistics } \\
\hline Small & 0.008 & -0.004 & 0.009 & 0.007 & -0.008 & Small & $\begin{array}{l}0.717 \\
(0.47)\end{array}$ & $\begin{array}{l}-0.480 \\
(0.63)\end{array}$ & $\begin{array}{l}0.995 \\
(0.32)\end{array}$ & $\begin{array}{l}0.803 \\
(0.42)\end{array}$ & $\begin{array}{l}-0.755 \\
(0.45)\end{array}$ \\
\hline Big & -0.021 & 0.008 & -0.007 & 0.002 & -0.002 & Big & $\begin{array}{l}-2.662 \\
(0.00) \\
\end{array}$ & $\begin{array}{l}0.946 \\
(0.34)\end{array}$ & $\begin{array}{l}-1.10 \\
(0.27)\end{array}$ & $\begin{array}{l}0.313 \\
(0.75) \\
\end{array}$ & $\begin{array}{r}-0.448 \\
(0.65) \\
\end{array}$ \\
\hline \multicolumn{6}{|c|}{ Coefficients of the HML Factor } & \multicolumn{6}{|c|}{ Coefficients of the RMW Factor } \\
\hline Small & $\begin{array}{l}-0.110 \\
(-0.34)\end{array}$ & $\begin{array}{l}0.394 \\
(1.45)\end{array}$ & $\begin{array}{c}0.082 \\
(0.30)\end{array}$ & $\begin{array}{l}0.251 \\
(0.91)\end{array}$ & $\begin{array}{l}-1.443 \\
(-4.53)\end{array}$ & Small & $\begin{array}{l}-1.719 \\
(-6.67)\end{array}$ & $\begin{array}{l}-0.114 \\
(-0.52)\end{array}$ & $\begin{array}{l}-0.363 \\
(-1.67)\end{array}$ & $\begin{array}{l}-0.348 \\
(-1.59)\end{array}$ & $\begin{array}{l}0.714 \\
(2.83)\end{array}$ \\
\hline Big & $\begin{array}{l}0.200 \\
(0.83) \\
\end{array}$ & $\begin{array}{l}-0.337 \\
(-1.37) \\
\end{array}$ & $\begin{array}{l}-0.178 \\
(-0.91) \\
\end{array}$ & $\begin{array}{l}0.056 \\
(0.32) \\
\end{array}$ & $\begin{array}{l}-0.069 \\
(-0.45) \\
\end{array}$ & Big & $\begin{array}{l}-0.808 \\
(-4.25) \\
\end{array}$ & $\begin{array}{l}-1.192 \\
(-6.12) \\
\end{array}$ & $\begin{array}{l}-0.624 \\
(-4.03) \\
\end{array}$ & $\begin{array}{l}-0.128 \\
(-0.90) \\
\end{array}$ & $\begin{array}{l}-0.275 \\
(-2.27) \\
\end{array}$ \\
\hline \multicolumn{6}{|c|}{ Coefficients of the CMA Factor } & \multicolumn{6}{|c|}{ Adjusted R2 (\%) } \\
\hline Small & $\begin{array}{l}0.802 \\
(3.04)\end{array}$ & $\begin{array}{l}-0.736 \\
(-3.30)\end{array}$ & $\begin{array}{l}-0.595 \\
(-2.67)\end{array}$ & $\begin{array}{l}-0.285 \\
(-1.27)\end{array}$ & $\begin{array}{l}-0.152 \\
(-0.59)\end{array}$ & Small & 65.21 & 69.15 & 51.58 & 31.44 & 71.11 \\
\hline Big & $\begin{array}{l}0.254 \\
(1.31) \\
\end{array}$ & $\begin{array}{l}0.372 \\
(1.86) \\
\end{array}$ & $\begin{array}{l}0.432 \\
(2.73)\end{array}$ & $\begin{array}{l}-0.153 \\
(-1.06)\end{array}$ & $\begin{array}{l}0.087 \\
(0.70)\end{array}$ & Big & 57.09 & 57.11 & 54.89 & 54.59 & 54.88 \\
\hline \multicolumn{12}{|c|}{ Panel C: Size-INV Portfolios } \\
\hline & Low & 2 & 3 & 4 & High & & Low & 2 & 3 & 4 & High \\
\hline \multicolumn{7}{|c|}{ Intercepts } & \multicolumn{5}{|c|}{ t-statistics } \\
\hline Small & -0.005 & -0.0003 & -0.007 & 0.012 & 0.007 & Small & $\begin{array}{l}-0.310 \\
(0.76)\end{array}$ & $\begin{array}{l}-0.028 \\
(0.98)\end{array}$ & $\begin{array}{l}-0.663 \\
(0.51)\end{array}$ & $\begin{array}{l}1.076 \\
(0.28)\end{array}$ & $\begin{array}{l}0.480 \\
(0.63)\end{array}$ \\
\hline Big & 0.001 & -0.006 & -0.011 & 0.002 & -0.006 & Big & $\begin{array}{l}0.122 \\
(0.90)\end{array}$ & $\begin{array}{c}-0.868 \\
(0.39) \\
\end{array}$ & $\begin{array}{c}-1.692 \\
(0.09) \\
\end{array}$ & $\begin{array}{l}0.347 \\
(0.73) \\
\end{array}$ & $\begin{array}{r}-1.010 \\
(0.31) \\
\end{array}$ \\
\hline \multicolumn{7}{|c|}{ Coefficients of the HML Factor } & \multicolumn{5}{|c|}{ Coefficients of the RMW Factor } \\
\hline Small & $\begin{array}{l}-2.427 \\
(-5.12)\end{array}$ & $\begin{array}{l}0.020 \\
(0.07)\end{array}$ & $\begin{array}{l}0.209 \\
(0.69)\end{array}$ & $\begin{array}{l}0.794 \\
(2.45)\end{array}$ & $\begin{array}{l}-0.118 \\
(0.45)\end{array}$ & Small & $\begin{array}{l}-1.648 \\
(-4.39)\end{array}$ & $\begin{array}{l}-0.320 \\
(-1.41)\end{array}$ & $\begin{array}{l}-0.379 \\
(-1.59)\end{array}$ & $\begin{array}{l}-0.569 \\
(-2.22)\end{array}$ & $\begin{array}{l}0.477 \\
(1.35)\end{array}$ \\
\hline Big & $\begin{array}{l}0.228 \\
(1.27) \\
\end{array}$ & $\begin{array}{l}0.323 \\
(1.52) \\
\end{array}$ & $\begin{array}{l}-0.346 \\
(-1.80) \\
\end{array}$ & $\begin{array}{l}-0.175 \\
(-0.90) \\
\end{array}$ & $\begin{array}{l}0.023 \\
(0.13)\end{array}$ & Big & $\begin{array}{l}-0.500 \\
(-3.50) \\
\end{array}$ & $\begin{array}{l}-0.690 \\
(-4.10) \\
\end{array}$ & $\begin{array}{l}-0.339 \\
(-2.21) \\
\end{array}$ & $\begin{array}{l}-0.152 \\
(-0.98) \\
\end{array}$ & $\begin{array}{l}-0.174 \\
(-1.21) \\
\end{array}$ \\
\hline \multicolumn{6}{|c|}{ Coefficients of the CMA Factor } & \multicolumn{6}{|c|}{ Adjusted R2 (\%) } \\
\hline Small & $\begin{array}{l}1.631 \\
(4.24)\end{array}$ & $\begin{array}{l}-0.041 \\
(-0.18)\end{array}$ & $\begin{array}{l}0.382 \\
(1.56)\end{array}$ & $\begin{array}{l}-0.405 \\
(-1.54)\end{array}$ & $\begin{array}{l}-1.798 \\
(-4.95)\end{array}$ & Small & 66.80 & 55.99 & 58.15 & 55.00 & 40.00 \\
\hline Big & $\begin{array}{l}0.242 \\
(1.66)\end{array}$ & $\begin{array}{l}0.533 \\
(3.09)\end{array}$ & $\begin{array}{l}0.191 \\
(1.22)\end{array}$ & $\begin{array}{l}0.091 \\
(0.58)\end{array}$ & $\begin{array}{l}-0.049 \\
(-0.33)\end{array}$ & Big & 53.78 & 56.57 & 50.70 & 54.04 & 53.67 \\
\hline
\end{tabular}

Note. Table 7 shows the slopes of the Fama and French five risk factors along with their t-statistics in parentheses, the intercepts of the Fama and French five-factor model and their t-statistics with the significance level in parentheses and adjusted $\mathrm{R}^{2}$ values of the full sample time-series regression of the Fama and French five-factor model applied on the 10 portfolios double-sorted on size and the BE/ME ratio, size and OP, and size and INV. The time-series regression is as follows:

$$
R_{i t}^{e}=\alpha_{i}+\beta_{i} R_{M t}^{e}+s_{i} S M B_{t}+h_{i} H M L_{t}+c_{i} C M A_{t}+r_{i} R M W_{t}+\varepsilon_{i t}
$$


Panel B reports the results for the 10 portfolios double-sorted on size and operating profitability. The inclusion of the RMW and CMA factors does not lead to significant changes in the results which can be attributed to the following reasons. First, although the coefficients of the RMW factor tend to increase with operating profitability as expected, they are mainly negative for all the portfolios except one which is inconsistent with the patterns depicted by Fama and French (2015) who argue that high profitability portfolios should load positively on the RMW factor. Second, as shown in Table 3, the RMW factor is insignificant in the Egyptian stock market and thus, its contribution towards explaining the cross-sectional variations in returns is insignificant. Third, although portfolios falling in the lowest profitability quintile in both size groups (SL and BL) have positive CMA coefficients which matches Fama-French (2015) proposition that conservative stocks have weak profitability, the coefficients of the CMA factor are significant only on 4 out of the 10 portfolios. Given these reasons, similar to the Fama and French three-factor model, the big portfolio with weak profitability remains to challenge the model by having a negative and significant intercept of $2.1 \%$.

Finally, Panel C of Table 7 reports the results for the 10 portfolios double-sorted on size and investment. Similar to the results of the Fama and French three-factor model, 9 out of the 10 portfolios in this sort have intercepts that are statistically insignificant. In addition, the results of Panel $\mathrm{C}$ show that the inclusion of the RMW and the CMA factors does not play a significant role in explaining the common variation in returns related to size and investment as the adjusted $\mathrm{R}^{2}$ values remain below $70 \%$ implying that the model leaves substantial variation in stock returns unexplained. These results can be attributed to the following reasons. First, although the coefficients of the CMA factor show patterns that are consistent with the arguments of Fama and French (2015) that portfolios with low (high) asset growth should load positively (negatively) on the CMA factor in the big portfolios, the patterns of the coefficients of the CMA factor in the small portfolios are less consistent with this argument. Second, only three out of the 10 portfolios double-sorted on size and investment have significant coefficients on the CMA factor which may explain the poor explanatory power of the model. Finally, since most of the coefficients of the RMW factor are negative and insignificant and the average return of the RMW is insignificant in the Egyptian stock market the inclusion of the RMW factor adds little to the explanatory power of the model.

To sum up, the results of this section show that the performance of the Fama and French five factor model is unsatisfactorily in the Egyptian stock market. Similar to the Fama and French three-factor model, the five-factor model leaves substantial variations in returns unexplained. This, in turn, open a fertile avenue for future research to test whether the inclusion of other risk factors can provide better explanation of the cross-sectional variation in stock returns in the Egyptian stock market. However, given the unfavorable results of both models, Fama and French (2015) emphasize that, since asset pricing models provide simplified propositions about the reality, researchers should be more interested in the relative performance of models rather than in whether these models are accepted or rejected. Thus, to compare between both model, the following section aims to provide the results of the GRS test to determine which model provide the best, but still incomplete, explanation of average returns in the Egyptian stock market.

\section{The Gibbons, Ross, and Shanken (GRS) Test}

The final time-series test of the Fama and French three-factor and five-factor models is the Gibbons, Ross, and Shanken (GRS) test. The Chi-Square statistic of the robust GRS test of the Fama and French three-factor model is 12.30 with a significance level of 0.26 which implies that the null hypothesis that the intercepts of the 10 size-BE/ME portfolios are jointly equal to zero is not rejected in the Egyptian stock market. Similarly, the Chi-Square statistic of the robust GRS test of the Fama and French five-factor model is 9.06 with a significance level of 0.53 . These results imply that although both models are not rejected when the 10 size-BE/ME portfolios are used as the main test assets, the Fama and French five-factor model is more favorable as it produces lower GRS statistic.

Using the 10 portfolios double-sorted on size and operating profitability as the main test assets, the results show that the Chi-Square statistics of the robust GRS test of the Fama and French three-factor and five-factor models are 22.11 and 21.632 respectively and both are statistically significant at the 5\% level. These results imply that the null hypothesis that all intercepts are equal to zero is strongly rejected. These results support the results of Table 6 and Table 7 that both models are strongly challenged with this set of portfolios. Despite these challenges, the results show that the five factor model provides a better, yet incomplete, explanation of the cross-sectional variation in stock returns than the Fama and French three-factor model.

Finally, using the 10 portfolios double-sorted on size and investment as the main test assets, the results show that the Chi-Square statistics of the robust GRS test of the Fama and French three-factor and five-factor models are 
10.38 and 10.785 respectively and both are statistically insignificant. These results imply that the null hypothesis that all the intercepts are equal to zero cannot be rejected for both models. Furthermore, the results show that the Fama and French three-factor model has a slightly lower GRS statistic compared to the five-factor model which indicates that it provides a slightly better explanation of the cross-sectional variations in returns related to size and investment than the five-factor model.

Overall, the results of this section support the results of Section 6 and Section 7 that the Fama and French three-factor and five-factor models cannot be considered as the best asset pricing models for the Egyptian stock market. Both models face severe challenges that hinder them from capturing the cross-sectional variation in stock returns. However, relative to the Fama and French three-factor model, the five-factor model can provide better description of average returns in the Egyptian stock market.

\section{Conclusion}

Recently, the focus of researchers, practitioners and investors is directed towards emerging markets given the tremendous investment opportunities offered in these markets. Nonetheless, emerging markets still pose significant challenges to standard asset pricing models due to their special features. Motivated by the increase in both domestic and foreign investments in Egypt especially after the economic reform program applied by the government, there is a crucial need to develop a valid asset pricing model for the Egyptian market that investors and practitioners can use in evaluating their investments. Thus, the aim of this paper is to test whether the Fama and French three-factor and five-factor models can capture the variations of returns in the Egyptian stock market related to size, the BE/ME ratio, operating profitability, and investments as they represent the most prominent anomalies in finance literature. To achieve this aim, this paper constructs the Fama and French factors for the Egyptian stock market following Fama and French (2015). Furthermore, this paper constructs and uses three sets of portfolios as test assets. The first set includes portfolios double-sorted on size and the BE/ME ratio, the second set includes portfolios double-sorted on size and operating profitability and the third set includes portfolios double-sorted on size and investment.

Testing for the existence of size, value, investment, and profitability patterns in the Egyptian stock market, the results reveal that the size effect is the most prominent anomaly in the Egyptian market. Furthermore, although the results provide some support for the existence of investment and profitability effects in the Egyptian market, they reveal that these patterns are not as significant as the size effect. Finally, in contrast to the vast amount of literature supporting the existence of value effect in both developed and emerging markets, the results document the absence of value effect in the Egyptian market. These anomalous patterns in returns in the Egyptian stock market pose challenges for both the Fama and French three-factor and five-factor models to explain.

In comparing between the Fama and French three-factor and five-factor models using time-series regression and the GRS test several results are revealed about the performance of both models in Egypt. First, consistent with Fama and French (2015), the results reveal that both models provide incomplete description of the returns in the Egyptian stock market. However, in focusing on the relative performance of both models, the results show that Fama and French five-factor models provide better explanation of stock returns in the Egyptian stock market than the three-factor model given the values of the adjusted $\mathrm{R}^{2}$ and the values of the GRS test.

These results suggest useful directions for future research in the Egyptian stock market. First, researchers should try to identify other risk factors that can provide better explanations of stock returns in the Egyptian stock market. Second, following Ghysels (1995), researchers should also be considered with identifying the appropriate model specification by relaxing the assumptions of constant betas and risk premia (Abdou, 2019) to provide better explanations of stock returns in the Egyptian stock market.

\section{References}

Abdou, R. (2019). Determinants of Stock Prices in the Egyptian Stock Market: Traditional Asset Pricing Models versus Behavioural Asset Pricing Models. PhD thesis, Faculty of Business and Law, University of the West of England, UK.

Aharoni, G., Grundy, B., \& Zeng, Q. (2013). Stock Returns and the Miller Modigliani Valuation Formula: Revisiting the Fama French Analysis. Journal of Financial Economics, 110, 347-357. https://doi.org/10.1016/j.jfineco.2013.08.003

Aretz, K., Bartram, S., \& Pope, P. (2010). Macroeconomic Risks and Characteristic-Based Factor Models. Journal of Banking and Finance, 34(6), 1383-1399. https://doi.org/10.1016/j.jbankfin.2009.12.006

Avramov, D., \& Chordia, T. (2006). Asset Pricing Models and Financial Market Anomalies. Review of Financial Studies, 19(3), 1001-1040. https://doi.org/10.1093/rfs/hhj025 
Banz, R. (1981). The Relationship between Return and Market Value of Common Stocks. Journal of Financial Economics, 9(1), 3-18. https://doi.org/10.1016/0304-405X(81)90018-0

Basu, S. (1977). Investment Performance of Common Stocks in Relation to their Price-Earnings Ratios: A Test of the Efficient Market Hypothesis. Journal of Finance, 32(3), 663-682. https://doi.org/10.1111/j.1540-6261.1977.tb01979.x

Black, F., Jensen, M., \& Scholes, M. (1972). The Capital Asset Pricing Model: Some Empirical Tests. Studies in the Theory of Capital Markets. New York: Praeger Publishers.

Cochrane, J. (2001). Asset Pricing (1st ed.). Princeton University Press.

Daniel, K., \& Titman, S. (2012). Testing Factor-Model Explanations of Market Anomalies. Critical Finance Review, 1(1), 103-139. https://doi.org/10.1561/104.00000003

Dash, S., \& Mahakud, J. (2014). Do Asset Pricing Models Explain Size, Value, Momentum and Liquidity Effects? The Case of an Emerging Stock Market. Journal of Emerging Market Finance, 13(3), 217-251. https://doi.org/10.1177/0972652714550927

Drew, M., \& Veeraraghavan, M. (2002). A Closer Look at the Size and Value Premium in Emerging Markets: Evidence from the Kuala Lumpur Stock Exchange. Asian Economic Journal, 16(4), 337-351. https://doi.org/10.1111/1467-8381.00156

El Abd, R. (2016). Determinants of Stock Returns: Evidence from Egypt. Master thesis, The American University in Cairo, Egypt.

El Sayed, S. (2018). Testing Factor Models in Emerging Markets: Evidence from the Egyptian Stock Market. Working paper.

Fama, E., \& French, K. (1992). The Cross-Section of Expected Stock Returns. Journal of Finance, 47(2), 427-465. https://doi.org/10.1111/j.1540-6261.1992.tb04398.x

Fama, E., \& French, K. (1996). Multifactor Explanations of Asset Pricing Anomalies. Journal of Finance, 51(1), 55-84. https://doi.org/10.1111/j.1540-6261.1996.tb05202.x

Fama, E., \& French, K. (1993). Common Risk Factors in the Returns on Stocks and Bonds. Journal of Financial Economics, 33(1), 3-56. https://doi.org/10.1016/0304-405X(93)90023-5

Fama, E. F., \& French, K. (2015). A Five-Factor Asset Pricing Model. Journal of Financial Economics, 116, 1-22. https://doi.org/10.1016/j.jfineco.2014.10.010

Fama, E. F., \& French, K. (2017). International Tests of a Five-Factor Asset Pricing Model. Journal of Financial Economics, 123(3), 441-463. https://doi.org/10.1016/j.jfineco.2016.11.004

Gibbons, M., Ross, S., \& Shanken, J. (1989). A Test of the Efficiency of a Given Portfolio. Econometrica, 57(55), 1121-1152. https://doi.org/10.2307/1913625

Ghysels, E. (1995). On Stable Factor Structures in the Pricing of Risk. Working Paper No. 95s-16, CIRANO Scientific Series.

Gregory, A., Tharyan, R., \& Christidis, A. (2013). Constructing and Testing Alternative Versions of the Fama-French and Carhart Models in the UK. Journal of Business Finance and Accounting, 40(1), 172-214. https://doi.org/10.1111/jbfa.12006

Jagannathan, R., \& Wang, Z. (1996). The Conditional CAPM and the Cross-Section of Expected Returns. Journal of Finance, 51(1), 3-53. https://doi.org/10.1111/j.1540-6261.1996.tb05201.x

Lakonishok, J., Shleifer, A., \& Vishny, R. (1994). Contrarian Investment, Extrapolation, and Risk. Journal of Finance, 49(5), 1541-1578. https://doi.org/10.1111/j.1540-6261.1994.tb04772.x

Lewellen, J., Nagel, S., \& Shanken, J. (2010). A Sceptical Appraisal of Asset Pricing Tests. Journal of Financial Economics, (96), 175-194. https://doi.org/10.1016/j.jfineco.2009.09.001

Lin, Q. (2017). Noisy Prices and the Fama-French Five-Factor Asset Pricing Model in China. Emerging Markets Review, 31, 141-163. https://doi.org/10.1016/j.ememar.2017.04.002

Lintner, J. (1965). Security Prices, Risk, and Maximal Gains from Diversification. Journal of Finance, 20(4), 587-615. https://doi.org/10.1111/j.1540-6261.1965.tb02930.x

Lozano, M. (2009). Econometrics of Asset Pricing: Methodological Review and Empirical Exercise. http://dx.doi.org/10.2139/ssrn.1754762 
Markowitz, H. (1952). Portfolio Selection. The Journal of Finance, 7(1), 77-91. https://doi.org/10.1111/j.1540-6261.1952.tb01525.x

Merton, R. (1973). An Intertemporal Capital Asset Pricing Model. Econometrica, 41(5), 867-887. https://doi.org/10.2307/1913811

Miller, M., \& Modigliani, F. (1961). Dividend Policy, Growth and the Valuation of Shares. Journal of Business, 34, 411-433. http://dx.doi.org/10.1086/294442

Mossin, J. (1966). Equilibrium in a Capital Asset Market. Econometrica, 34(4), 768-783. https://doi.org/10.2307/1910098

Novy-Marx, R. (2013). The Other Side of Value: The Gross Profitability Premium. Journal of Financial Economics, 108(1), 1-28. https://doi.org/10.1016/j.jfineco.2013.01.003

Ross, S. (1976). The arbitrage Theory of Capital Asset Pricing. Journal of Economic Theory, 13(3), 341-360. https://doi.org/10.1016/0022-0531(76)90046-6

Ross, S. (1978). The Current Status of the Capital Asset Pricing Model (CAPM). Journal of Finance, 33(3), 885-901. https://doi.org/10.2307/2326486

Shah, S., Ghafoor, A., \& Khan, M. (2014). Estimation of Fama and French Model with Augmented Risk Factors: Case of KSE-Pakistan. International Journal of Business and Management, 9(9), 161-175. https://doi.org/10.5539/ijbm.v9n9p161

Shaker, M., \& Elgiziry, K. (2014). Asset Pricing Tests in the Egyptian Stock Market. Accounting and Finance Research, 3(4), 24-30. https://doi.org/10.5430/afr.v3n4p24

Sharpe, W. (1964). Capital Asset Prices: A Theory of Market Equilibrium under Conditions of Risk. Journal of Finance, 19(3), 425-442. https://doi.org/10.1111/j.1540-6261.1964.tb02865.x

\section{Note}

Note 1. (i) The CAPM, (ii) the Carhart model, (iii) the liquidity -augmented Fama and French three-factor model (Chan and Faff, 2005) and (iv) the liquidity and momentum-augmented Fama and French three-factor model.

\section{Copyrights}

Copyright for this article is retained by the author(s), with first publication rights granted to the journal.

This is an open-access article distributed under the terms and conditions of the Creative Commons Attribution license (http://creativecommons.org/licenses/by/4.0/). 